\title{
Anti-inflammatory and Anti-apoptotic Effect of Valproic Acid and Doxycycline Independent from MMP Inhibition in Early Radiation Damage
}

\author{
Ferda Hoşgörler ${ }^{1}$, Didem Keleş², Serpil Tanrıverdi-Akhisaroğlu ${ }^{3}$, Şeniz İnanç², Mustafa Akhisaroğlu ${ }^{4}$, \\ Ülker Cankurt ${ }^{5}$, Zekiye Aydoğdu ${ }^{6}$, Ahmet Deniz Uçarr ${ }^{1}$, Ogguz Çetinayak ${ }^{7}$, Gülgün Oktay², \\ Sevil Gönenç $\mathrm{Arda}^{4}$

\begin{abstract}
${ }^{1}$ Department of General Surgery, Bozyaka Training and Research Hospital, İzmir, Turkey
${ }^{2}$ Department of Medical Biochemistry, Dokuz Eylül University School of Medicine, İzmir, Turkey

${ }^{3}$ Department of Molecular Medicine, Dokuz Eylül University Health Science Institute, İzmir, Turkey

${ }^{4}$ Department of Physiology, Dokuz Eylül University School of Medicine, İzmir, Turkey

${ }^{6}$ Department of Pathology, Dr. Suat Seren Teaching Hospital, İzmir, Turkey

${ }^{7}$ Department of Radiation Oncology, Dokuz Eylül University School of Medicine, İzmir, Turkey
\end{abstract} \\ ${ }^{5}$ Department of Histology and Embryology, Dokuz Eylül University School of Medicine, İzmir, Turkey
}

Background: Matrix metalloproteinase (MMP) inhibitors decrease inflammation in normal tissues and suppress cancer progress in normal tissues. Valproic acid (VA) and doxycycline (DX) are MMP inhibitors that have radio-protective effects. Their ability to inhibit MMPs in irradiated tissue is unknown and the role of MMPs in radio-protective effects has not been tested to date.

Aims: The purpose of this study was to examine whether administration of VA and DX to rats before irradiation affects tissue inflammation and apoptosis in the early phase of radiation, and whether the effect of these drugs is mediated by MMP inhibition.

Study Design: Animal experimentation.

Methods: Twenty-six Wistar rats were randomized into four groups: control (CTRL), radiation (RT), VA plus radiation $(\mathrm{VA}+\mathrm{RT})$, and $\mathrm{DX}$ plus radiation $(\mathrm{DX}+\mathrm{RT})$. Three study groups were exposed to a single dose of abdominal 10 Gy gamma radiation; the CTRL group received no radiation. Single doses of VA $300 \mathrm{mg} / \mathrm{kg}$ and DX $100 \mathrm{mg} / \mathrm{kg}$ were administered to each rat before radiation and all rats were sacrificed 8 hours after irradiation, at which point small intestine tissue samples were taken for analyses. Levels of inflammatory cytokines (TNF- $\alpha$, IL-1 $\beta$, and IL-6) and matrix metalloproteinases (MMP-2 and MMP 9) were measured by ELISA, MMP activities were measured by gelatin and casein zymography and apoptosis was assessed by terminal deoxynucleotidyl transferase dUTP nick end labeling assay.

Results: VA decreased the levels of TNF- $\alpha$ and IL-1 $\beta$ proteins insignificantly and decreased apoptosis significantly in the irradiated tissue, but did not inhibit MMPs. In contrast, VA protected the basal MMP activities, which decreased in response to irradiation. No effect of DX was observed on the levels of inflammatory cytokines or activities of MMPs in the early phases of radiation apoptosis.

Conclusion: Our findings indicated that VA protects against inflammation and apoptosis, and DX exhibits anti-apoptotic effects in early radiation and these effects are independent from MMP inhibition.

Keywords: Matrix metalloproteinase, radiation, valproic acid, doxycycline 
During tumor ablation with radiotherapy, injury of the surrounding healthy tissue leads to considerable side effects. Radiotherapy of abdominopelvic tumors frequently damages the small intestine. Acute radiation damage in the small intestine begins within hours, with the activation of transcription factors, inflammatory cytokines, and apoptosis leading to mucosal degradation $(1,2)$.

Matrix metalloproteinases (MMPs) play a critical role in tissue remodeling by degrading the matrix and connective tissue proteins. In pathological situations such as radiation damage protein levels of MMPs are increased (3). Levels of inflammatory cytokines and activities of MMPs are elevated concomitantly in the acute phase of radiation-induced intestinal inflammation (4). MMPs can aggravate or suppress inflammation by enzymatically changing the structure and function of inflammatory substrates $(5,6)$.

Tetracycline derivatives are antimicrobial agents that have MMP inhibitory effects. Doxycycline (DX) is the strongest non-specific MMP inhibitor known within this group. Through MMP-2 and MMP-9 inhibition, DX reduces cell invasion and migration in cancer cells, and elicits anti-inflammatory features in normal tissues $(7,8)$.

Valproic acid (VA), which is used as a treatment for epilepsy, is a class 1 histone deacetylase inhibitor. VA has anti-inflammatory effects, mediated by MMP-9 inhibition (9). Similarly to DX, VA has anti-cancer effects, mediated by inhibition of MMP-2 and MMP-9 (10). Radiation injury experiments indicate that VA and DX elicit radioprotective effects through various mechanisms $(11,12)$. However, the effect of VA and DX on MMP inhibition has not been tested before in radiationdamaged tissue. The purpose of this study was to examine the effects of VA and DX on tissue inflammation and apoptosis associated with MMP during early radiation damage.

VA and DX have useful effects on radiation damage, inflammation, and cancer processes and also have low toxicity and are low cost. Therefore, their effectiveness in radiotherapy is of interest. This is the first study to examine the radio-protective effectiveness of VA and DX in vivo in relation to MMPs in the first hours of radiation damage.

\section{MATERIALS AND METHODS}

\section{Experimental groups, irradiation, and drug treatment}

For this study, 26 Wistar albino male rats weighing 250-300 g were supplied by the Dokuz Eylül University Animal Laboratory. The experiments were conducted under non-sterile, clean conditions at room temperature. The rats were kept in standard laboratory conditions, with a 12-hour dark and light cycle and free access to water and food. All experimental pro- cedures were conducted according to the NIH Guide for the Care and Use of Laboratory Animals (1985). The experiments were approved by the Dokuz Eylül University Ethics Committee for Animal Experimentation.

Radiation, drug medication and tissue collection were performed under anesthesia, and all efforts were made to minimize the suffering of animals. The rats were randomly divided into four groups: Control (CTRL) group $(n=5)$, radiotherapy (RT) group $(n=7)$, VA+RT $(n=7)$, and DX+RT group $(n=7)$. The CTRL group was not treated with any drug or radiation. In the other three groups, a single dose of 10 Gy gamma radiation was delivered to the abdominal region. The radiation treatment was performed at the Dokuz Eylül University Medical School Department of Radiation Oncology. The radiation dose was selected in accordance with those used in a previous study (13). Radiation was applied by focusing a Theratron Co 60 device generating 1.25 MV photon energy on the skin from a distance of $100 \mathrm{~cm}$, and the dose of radiation was $1 \mathrm{~Gy} /$ min. The drugs were administered 1 hour before exposure to radiation. The $\mathrm{RT}$ group received $10 \mathrm{mg} / \mathrm{kg}$ physiological saline solution (Biofleks; Biosel İlaç A.Ş, İstanbul, Turkey) via subcutaneous (SC) injection. The VA+RT group received VA. Sodium valproate (Depakin, Sanofi Aventis; İstanbul, Turkey) $400 \mathrm{mg}$ lyophilized powder was mixed with sterile injectable water and $300 \mathrm{mg} / \mathrm{kg}$ administered subcutaneously (SC). The $\mathrm{DX}+\mathrm{RT}$ group received $100 \mathrm{mg} / \mathrm{kg}$ intramuscular (IM) DX monohydrate solution $(200 \mathrm{mg}$ per $\mathrm{mL}$ ready solution for injection) (Doksilin LA, Provet; İstanbul, Turkey). The VA dose required for MMP inhibition was determined on the basis of that reported in a previous study (14). DX was administered as a single dose of $100 \mathrm{mg} / \mathrm{kg}$ since the recommended DX longacting injectable dose was $70-100 \mathrm{mg} / \mathrm{kg}$ in rat medication (15). For anesthesia, an intraperitoneal mixture containing 80 $\mathrm{mg} / \mathrm{kg}$ ketamine (Ketalar, Pfizer; İstanbul, Turkey) and $7 \mathrm{mg} /$ $\mathrm{kg}$ xylazine (Basilazin 2\%; Bavet, İstanbul, Turkey) was used. All rats were sacrificed 8 hours after radiation, and small intestine tissue samples $10 \mathrm{~cm}$ away from the ileocecal valve were collected for analyses.

\section{ELISA}

Colon tissues $(50 \mathrm{mg})$ were homogenized in lysis buffer (150 mM NaCl, 0.1\% SDS, 0.1\% NP-40, 20 mM Tris-HCl pH 7.5 and protease inhibitor cocktail) using a Tissue Lyser II homogenizer (Qiagen; Hilden, Germany). Total protein concentrations of tissue homogenates were detected by BCA (bicinchoninic acid) assay (Thermo Scientific; Rockford, IL, USA).

The protein levels of TNF- $\alpha$ (Invitrogen; Carlsbad, CA, USA), IL-1 $\beta$, IL-6 (Bio Scientific; Austin, TX, USA), MMP2, and MMP-9 (USCN Life Science Inc.; Wuhan, China) in the tissue samples were determined using commercially avail- 
able sandwich ELISA kits, according to the protocol recommended by the manufacturer. Results were recorded using the ratio of detected protein (TNF- $\alpha$, IL-1 $\beta$, IL-6, MMP-2, and MMP-9) $(\mathrm{pg} / \mathrm{mL})$ to the amount of total protein $(\mu \mathrm{g} / \mathrm{mL})$.

\section{Gelatin and casein zymography assay}

Gelatin zymography and casein zymography were performed according to the method of Heussen and Dowdle with some modifications (16). Tissue samples $(50 \mathrm{mg})$ homogenized with Tissue Lyser II homogenizer (Qiagen; Hilden, Germany) in lysis buffer containing $50 \mathrm{mM}$ Tris- $\mathrm{HCl}(\mathrm{pH} 7.0), 10 \mathrm{mM} \mathrm{CaCl}_{2}$, $0.15 \mathrm{M} \mathrm{NaCl}, 0.05 \%$ Brij 35 and total protein concentrations were determined via BCA assay (Thermo Scientific; Rockford, IL, USA). Gelatin zymogram gels containing $1 \mathrm{mg} / \mathrm{mL}$ gelatin substrate were used to analyze MMP-2 and MMP-9 activity levels, whereas casein zymogram gels containing $1 \mathrm{mg} / \mathrm{mL}$ $\beta$-casein substrate were used to detect MMP-7 activity levels. Samples were electrophoretically separated at a constant voltage of $120 \mathrm{~V}$ for $2 \mathrm{~h}$ at $+4^{\circ} \mathrm{C}$ (Bio-Rad Life Science Hercules; CA, USA) under non-reducing and non-denaturing conditions. The gels were washed twice in $2.5 \%(\mathrm{v} / \mathrm{v})$ Triton X-100 at room temperature to remove SDS and renature MMPs. Zymogram gels were then incubated overnight at $37^{\circ} \mathrm{C}$ in a zymogram developing buffer $\left(0.5 \mathrm{M}\right.$ Tris-base, $0.1 \mathrm{M} \mathrm{CaCl}_{2}, 0.5 \mathrm{M} \mathrm{NaCl}$, $0.5 \%$ Brij 35, $\mathrm{pH}$ 7.6). The gels were stained with $0.5 \% \mathrm{Coo}-$ massie Blue R-250 for 2 hours at room temperature and destained in $20 \%$ acetic acid and $40 \%$ ethanol in distilled water. Pro-forms and active forms of MMPs were defined as clear bands against a dark background of stained substrate. Recombinant human MMP-2, MMP-7, and MMP-9 proteins (R\&D Systems; Minneapolis, MN, USA) were used as positive controls. For densitometry analysis, the area $\left(\mathrm{mm}^{2}\right)$ and optical density $\left(\mathrm{O} . \mathrm{D} / \mathrm{mm}^{2}\right)$ of latent and active bands of MMP-2, MMP-7, and MMP-9 were determined using UVP Bioimaging Systems with LabWorks 4.6 Image Acquisition Software (UVP Inc.; Upland, CA, USA). The activity levels were represented as specific proteinase activity (areaxoptical density/ $\mu \mathrm{g}$ of protein).

\section{TUNEL assay}

Apoptotic cell death was evaluated by the TUNEL method using an In situ Cell Death Detection Kit, POD (Roche; Mannheim, Germany). Briefly, sections were deparaffinized, rehydrated in graded alcohol, and microwave-pretreated in $0.5 \%$ trypsin at $37^{\circ} \mathrm{C}$ for $30 \mathrm{~min}$. After washing in phosphatebuffered saline, the specimens were incubated with the reaction mixture (TUNEL kits, Roche; Mannheim, Germany) at $37^{\circ} \mathrm{C}$ for $60 \mathrm{~min}$. After washing, Converter-POD (TUNEL kits, Roche; Mannheim, Germany) was applied to the slides. Sections were stained with diamino benzidine, counter-stained with hematoxylin, and mounted with entellan.
The stained transverse sections were photographed at $40 \mathrm{x}$ magnification (Olympus BX-51 Tokyo microscope). Fifty crypts were randomly selected for each group for the photos, and the apoptotic epithelial cells were counted. Apoptotic cells were selected according to the description of Kerr and Negoescu and colleagues $(17,18)$. Cells with brown nuclear staining and small apoptotic bodies, which were considered to be derived from a single cell, were counted. The apoptotic index was calculated using the following formula: (number of apoptotic cells/number of total cells)x 100 .

\section{Statistical analysis}

Statistical analyses were performed using GraphPad Prism software version 5.00, Inc. (La Jolla; CA, USA). Multiple groups were compared using the Kruskal-Wallis test. Bonferroni correction with Mann-Whitney $\mathrm{U}$ test was performed for comparison of two groups. P values less than 0.0125 were accepted to be statistically significant.

\section{RESULTS}

\section{Changes in the levels of inflammatory cytokines and apoptosis in response to radiation, $\mathrm{VA}$, and $\mathrm{DX}$}

Eight hours after exposure to $10 \mathrm{~Gy}$ abdominal gamma radiation, protein levels of TNF- $\alpha$, IL- 6 and IL-1 $\beta$ (CTRL, $0.002 \pm 0.0009 \mathrm{pg} / \mu \mathrm{g}$ protein; RT, $0.006 \pm 0.001 \mathrm{pg} / \mu \mathrm{g}$ protein, $\mathrm{p}=0.030$; Figure 1a. CTRL, 0 ; RT, $0.04 \pm 0.01 \mathrm{pg} / \mu \mathrm{g}$ protein; $\mathrm{p}=0.005$; Figure $1 \mathrm{~b}$. CTRL, $0.05 \pm 0.02 \mathrm{pg} / \mu \mathrm{g}$ protein; RT, $0.3 \pm 0.09 \mathrm{pg} / \mu \mathrm{g}$ protein; $\mathrm{p}=0.07$; Figue $1 \mathrm{c}$, respectively) were increased compared to the CTRL group. The increases in protein levels of TNF- $\alpha$ and IL-1 $\beta$ were not significant. In the $\mathrm{VA}+\mathrm{RT}$ group, protein levels of TNF- $\alpha$, IL- 6 and IL- $1 \beta$ were lower in comparison to those in the RT group, but the reductions were not significant (RT, $0.006 \pm 0.001 \mathrm{pg} / \mu \mathrm{g}$; VA+RT, $0.002 \pm 0.0007 \mathrm{pg} / \mu \mathrm{g}$ TNF- $\alpha ; \mathrm{p}=0.0303 ; \mathrm{RT}, 0.019 \pm 0.003 \mathrm{pg} /$ $\mu \mathrm{g}$; VA+RT, $0.010 \pm 0.006 \mathrm{pg} / \mu \mathrm{g}$ IL-6; $\mathrm{p}=0.08$; RT, $0.30 \pm 0.09$ $\mathrm{pg} / \mu \mathrm{g}$; VA+RT, $0.04 \pm 0.02 \mathrm{pg} / \mu \mathrm{g}$ IL- $1 \beta ; \mathrm{p}=0.0379$, respectively; Figure 1a-c). In the DX+RT group, there was no significant change in the levels of inflammatory cytokines compared to that in the RT group (RT, $0.006 \pm 0.001 \mathrm{pg} / \mu \mathrm{g}$; DX+RT, $0.007 \pm 0.0009 \mathrm{pg} / \mu \mathrm{g}$ TNF- $\alpha$; $\mathrm{p}=0.5 ; \mathrm{RT}, 0.019 \pm 0.003 \mathrm{pg} / \mu \mathrm{g}$; $\mathrm{DX}+\mathrm{RT}, 0.02 \pm 0.007 \mathrm{pg} / \mu \mathrm{g}$ IL-6; $\mathrm{p}=0.34$; RT, $0.30 \pm 0.09 \mathrm{pg} /$ $\mu \mathrm{g} ; \mathrm{DX}+\mathrm{RT}, 0.21 \pm 0.07 \mathrm{pg} / \mu \mathrm{g}$ IL-1 $\beta$; $\mathrm{p}=0.53$, respectively; Figure 1a-c).

Irradiation resulted in a significant increase in the apoptotic index compared to that observed in the CTRL group (CTRL, 9 \pm 2 ; RT, 12.6 \pm 0.7 ; $\mathrm{p}=0.0018$; Figure 2a,b). However, apoptosis was significantly lower in both the VA+RT group (Figure 2c) and DX+RT group (Figure 2d) compared to the RT group 
a

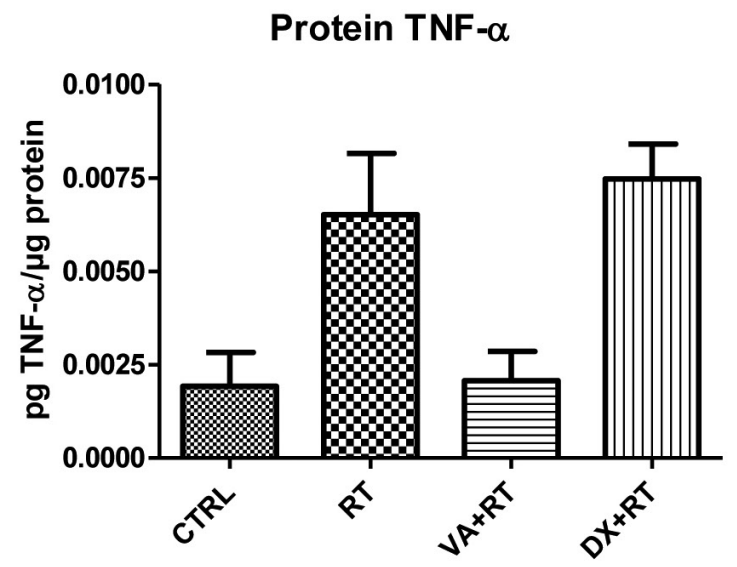

b

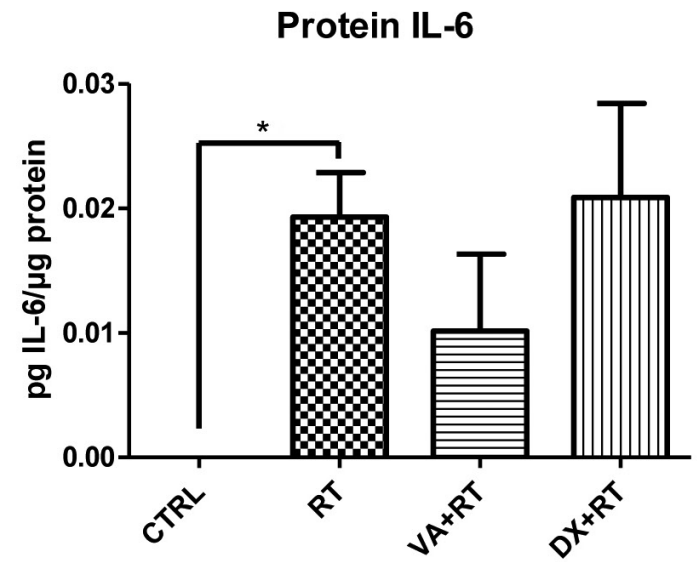

C

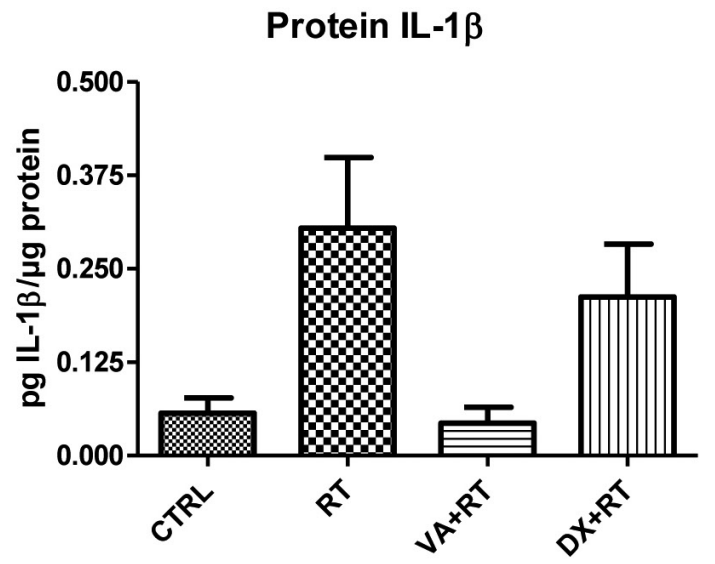

FIG. 1. a-c. TNF- $\alpha$ protein level. TNF- $\alpha$ protein level was decreased in $V A+R T$ and CTRL groups compared to RT group, but the decrease was insignificant (a). IL-6 protein level. IL-6 protein level was significantly increased in RT group compared to CTRL group (b). IL-1 $1 \beta$ protein level. IL-1 $\beta$ protein level was decreased in VA+RT and CTRL groups compared to RT group but the decrease was insignificant (c). $\left({ }^{*} p<0.0125\right.$. CTRL: control; RT: radiation; VA: valproic acid; DX: doxycycline)
(RT, 12.6 \pm 0.7 ; VA+RT, 9.9 $\pm 1.5 ; \mathrm{DX}+\mathrm{RT}, 10.5 \pm 1.2 ; \mathrm{p}=0.0116$ and $\mathrm{p}=0.0004$, respectively. Figure $2 \mathrm{e}$ ).

\section{Changes in MMP expression and activity in response to radiation, VA, and DX}

Eight hours after radiation exposure, the MMP-2 protein level in all groups was the same (Figure 3a) but there was an increase in MMP-9 protein level in the RT group compared to that observed in the CTRL group (CTRL, $0.005 \pm 0.002 \mathrm{pg} /$ $\mu \mathrm{g}$; RT, $0.1 \pm 0.03 \mathrm{pg} / \mu \mathrm{g}, \mathrm{p}=0.0057$; Figure $3 \mathrm{~b}$ ). In the VA+RT group and DX+RT group, MMP-2 and MMP-9 levels were similar to those in the RT group.

The gelatin zymography assay used to evaluate MMP activity indicated that irradiation significantly decreased the proform of MMP-2 (CTRL, 3514 \pm 297 ; RT, 228 \pm 47 in pro-form MMP-2; $\mathrm{p}=0.0025$; Figure 4a,b). The activity of the MMP2 active form was below the level of detection in the CTRL group and increased minimally in the RT group (Figure 4a). MMP-9 pro- and active forms were not observed in the CTRL and RT groups. Using casein zymogram gels, we detected prominent MMP-7 activity in the CTRL group (Figure 4c). In the RT group, the activities of both the pro-form and the active-form of MMP-7 were significantly suppressed compared to that observed in the CTRL group (CTRL, $1240 \pm 173$; RT, $11 \pm 2$ in pro-form MMP-7; $p=0.0025$ and CTRL, 1841 \pm 259 ; RT, $7 \pm 2$ in active-form MMP-7; $p=0.0025$, respectively; Figure $4 \mathrm{c}$ and $4 \mathrm{~d}$ ). In the VA+RT group, the activities of the MMP-2 pro- and active forms and MMP-7 pro- and active forms were increased compared to those observed in the RT group, but significant increases were only found in the proand active forms of MMP-7 (RT, 228 \pm 47 ; VA, $758 \pm 148$ in pro-form MMP-2; $\mathrm{p}=0.026$ and RT, $50 \pm 12$; VA, $1779 \pm 514$ in active-form MMP- $2 ; \mathrm{p}=0.026$, respectively, Figure $4 \mathrm{a}$ and $4 \mathrm{~b}$ and RT, $11 \pm 2$; VA, $1178 \pm 541$ in pro-form MMP-7; $=0.0006$ and RT, $7 \pm 2$; VA, $750 \pm 253$ in active-form MMP-7; $=0.0041$, respectively; Figure $4 \mathrm{c}$ and $4 \mathrm{~d})$. In the DX+RT group, there was no significant difference in activities of MMP-2 and MMP-7 pro- and active forms compared to those in the RT group (Figure 4d).

\section{DISCUSSION}

In our study, we observed increases in the level of inflammatory cytokines after abdominal irradiation. We detected a significant increase in the IL-6 protein level 8 hours after radiation. In irradiated tissues, we observed elevated levels of inflammatory cytokines together with an increased MMP-9 protein level. Previous studies indicated that a single dose of $10 \mathrm{~Gy}$ radiation induces MMP-2 and MMP-9 expression in rat brain tissues at 

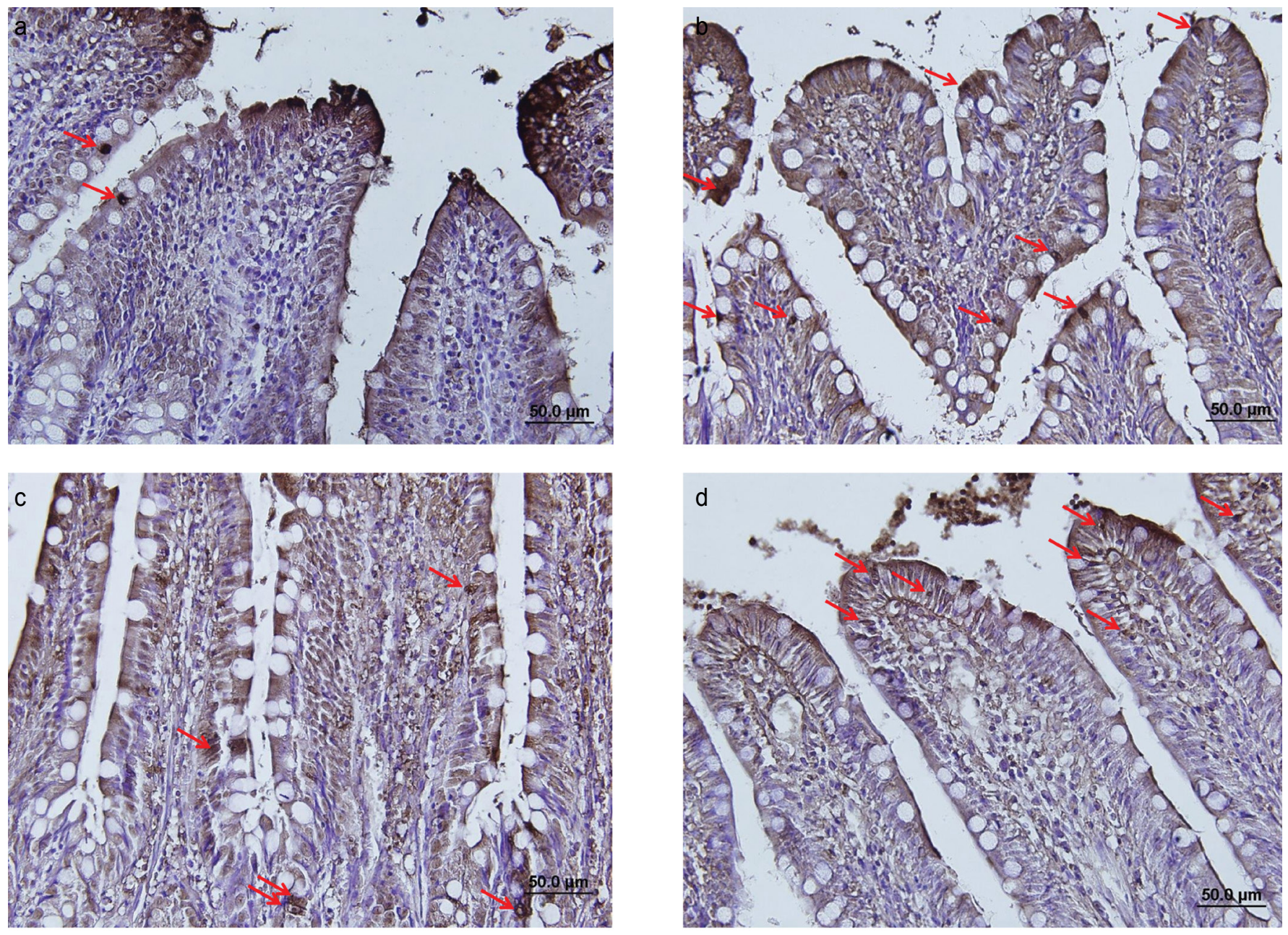

e

\section{Apoptosis}

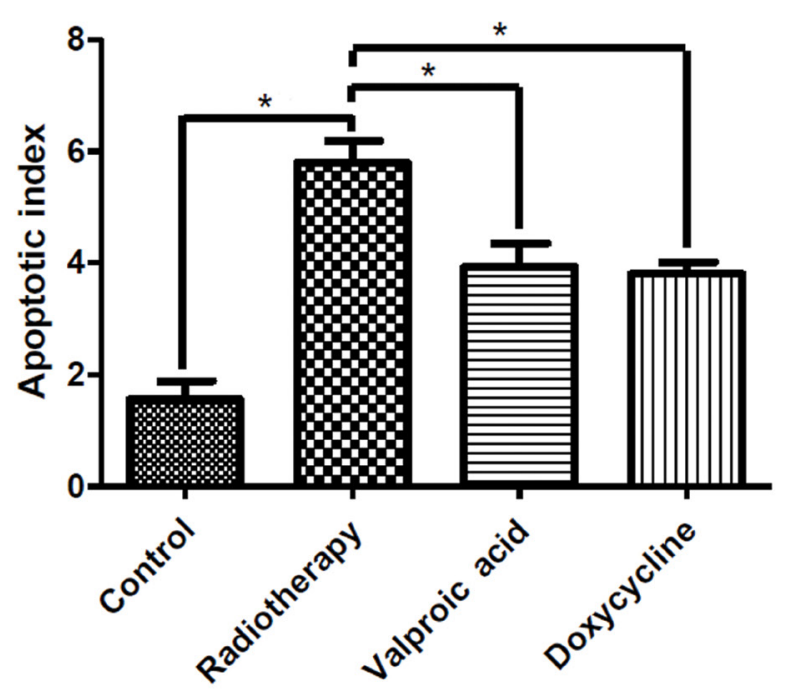

FIG. 2. a-e. TUNEL assay. Apoptotic cells (arrows) were stained brown in the villus epithelium in the CTRL group (a,b,c,d). TUNEL assay. Radiationinduced apoptosis was increased significantly in RT group compared to CTRL group. Radiation-induced apoptosis was decreased significantly in VA+RT group and DX+RT group compared to RT group (e). ( ${ }^{*} \mathrm{p}<0.0125$. CTRL: control; RT: radiation; VA: valproic acid; DX: doxycycline) 
a

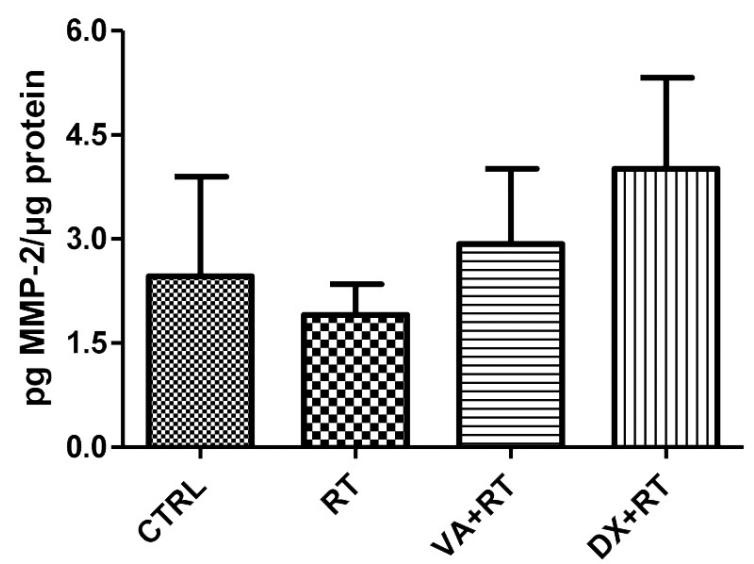

b

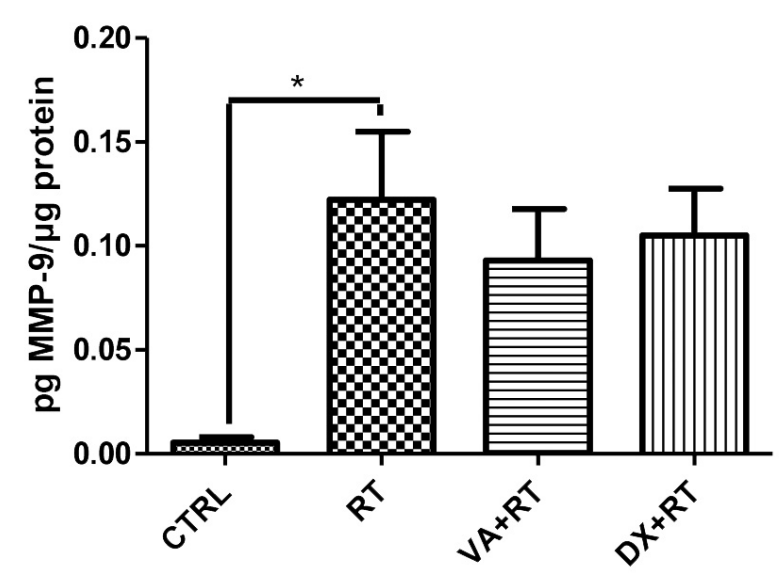

FIG. 3. a, b. MMP-2 protein level. There was no change in MMP-2 protein level in any group (a). MMP-9 protein level. MMP-9 protein level increased significantly in RT group compared to CTRL group. There was no change in MMP-9 level in VA+RT and DX+RT groups compared to RT group (b). ( ${ }^{*} p<0.0125$. CTRL: control; RT: radiation; VA: valproic acid; DX: doxycycline)
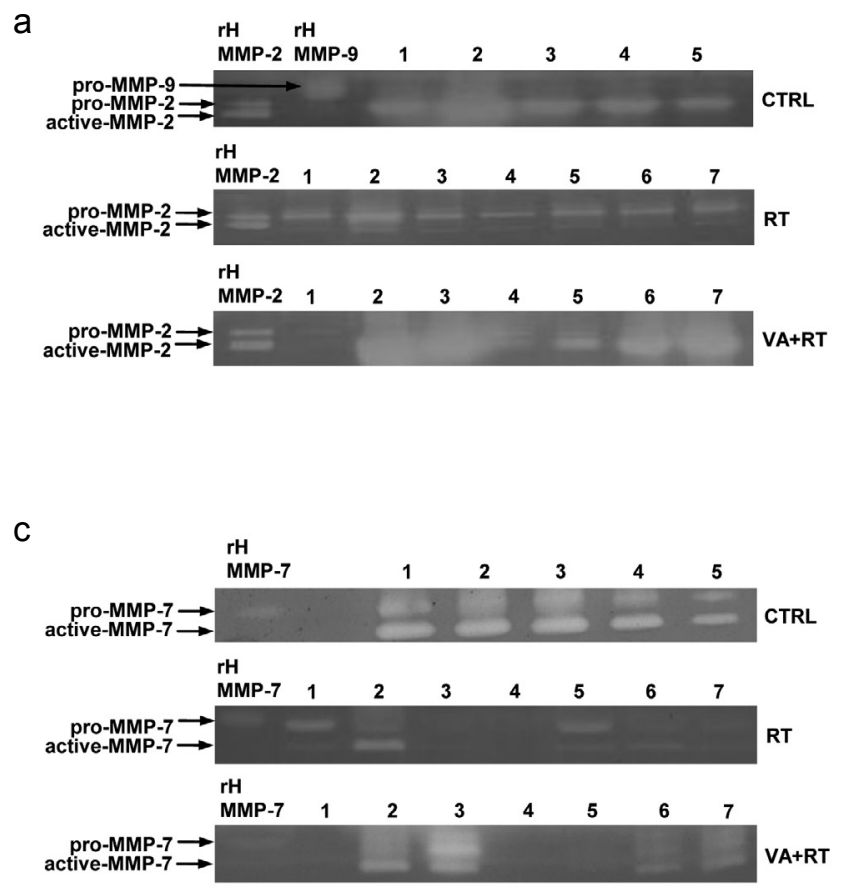

b
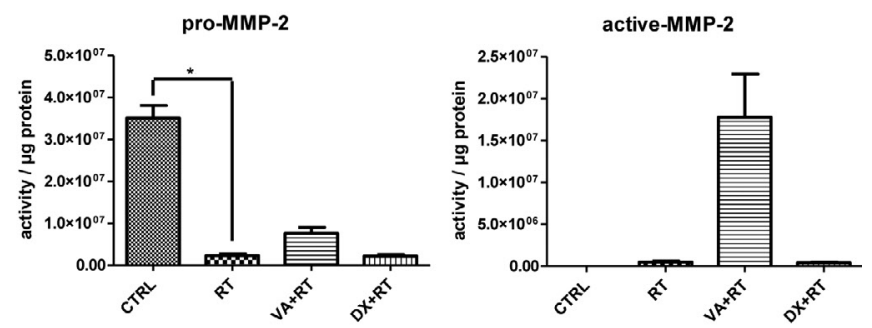

d
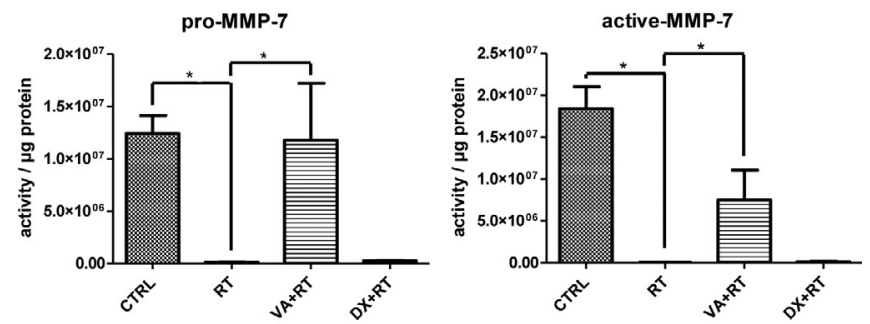

FIG. 4. a-d. Gelatin zymography. Pro- and active forms of MMPs were separated electrophoretically using zymography gels. Pro- and active forms of MMP-9 were below the level of detection in CTRL and RT groups. Activity of pro-MMP-2 was decreased in RT group compared to CTRL group (a). Activity of pro- and active forms of MMP-2 increased in VA+RT group in comparison with that observed in RT group, but the increase was insignificant (b). Casein zymography. Activities of the pro- and active forms of MMP-7 were suppressed in RT group when compared with CTRL group (c). Casein zymography. Activities of the pro- and active forms of MMP-7 were increased in VA+RT and CTRL groups when compared with RT group (d). ( ${ }^{*} p<0.0125$. CTRL: control; RT: radiation; VA: valproic acid; DX: doxycycline)

8-24 hours (19) and that preoperative radiotherapy increases MMP-2 and MMP-9 protein levels within a week in rectal mucosa (3). It is clear that the production of inflammatory cyto- kines and MMPs is induced by radiation soon after exposure. MMP activation is implicated in several physiological and pathological conditions such as remodeling of extracellular matrix, 
wound healing, tumor progression, uterine involution, bone resorption and intestinal fibrosis as a delayed effect of postradiation injury. Medina and Radomski reported that MMPs are transcriptionally inducible by TNF- $\alpha$ and IL- $1 \beta$ cytokines and that inflammatory cytokine levels together with MMP levels increase in inflammatory bowel disease (20).

The role of MMPs in acute inflammation of intestine subjected to radiation is unknown. It is likely that MMP-2 and MMP-9 expression is triggered by inflammation and/or radiation but the effect on and response of MMPs in irradiated tissue at early stages are unclear.

Strup-Perrot et al. and Hovdenak et al. $(4,21,22)$ found increased gelatinolytic activity in acute and late radiation injury but unchanging activity was detected by Kumar in late radiation injury. Another study suggested that MMP-2 activity is suppressed by RECK protein in pancreatic cancer cell lines (23). This subject is controversial and until the present study there has been no detailed knowledge of how MMP activity is affected during the early acute phases of radiation in intestinal tissue. Therefore we focused on early stage processes. However, after radiation, there was no increase in MMP-9 activity, and a surprising decrease in MMP- 2 and MMP-7 activities. The discrepancy between decreased MMP-2, MMP-7 and undetectable MMP-9 activity versus increased MMP-9 expression may be attributed to radiation-induced damage of the MMP protein structure through either a direct or an indirect mechanism, or due to the interaction of MMPs with other inhibitors.

In the current study we reported that attenuated MMP activity is alleviated by VA in irradiated tissue. In addition to this, VA reduced inflammatory cytokine levels but it was statistically insignificant. There is experimental evidence that MMPs can potentiate inflammatory processes by cleavage of chemokines and cytokines or can suppress these processes by degrading them $(24,25)$. In an experimental study it was shown that IL-1 $\beta$ stimulated MMP production and furthermore that abundant MMPs were responsible for the degradation of IL$1 \beta$ (5). In our study MMP activities increased and inflammatory cytokine levels tended to decrease in the VA group while the opposite occurred in the RT group. These results support the notion that MMPs have a degrading effect on inflammatory cytokines in the early phases of radiation and that sustained MMP activity may be in part necessary for the prevention of inflammation and apoptosis.

VA and other histone deacetylase inhibitors were identified as protecting agents against radiation damage because they suppress cutaneous fibrosis and increase wound healing in late phases (11). Their radio-protective effects have also previously been associated with reduced apoptosis (26). On the other hand VA has a radio-sensitizing effect on cancer cells through apoptosis induction (27). Our data on the radio-protective ef- fect of VA are consistent with previous studies. Additionally, our experiment demonstrated the effect of VA on earlier processes following a single prophylactic dose. VA is a promising drug because of its pro-apoptotic effect on cancer cells and anti-apoptotic and anti-inflammatory effects on normal cells in irradiated tissue.

Although DX is a powerful MMP inhibitor, it had no apparent effect on the expression and activity of inflammatory cytokines and MMPs. This may be due to the dose of drug administered or the administration of a single dose. This is consistent with a previous study, in which DX had no MMP inhibitory effect when administered as a $10 \mathrm{mg} / \mathrm{kg}$ single dose in vivo (28). However, in another study, doses of 50 and 500 $\mathrm{mg} / \mathrm{kg} /$ day had an inhibitory effect on MMP activities (29). Long-acting injectable DX administered at $70-100 \mathrm{mg} / \mathrm{kg} \mathrm{SC}$ or IM was recommended for rat antibiotherapy (15). Since our study aimed to achieve MMP inhibition with a single prophylactic dose of DX before radiation, we used injection as the preferred route of administration. When we administered 100 $\mathrm{mg} / \mathrm{kg}$ DX via IM, MMP inhibition did not occur; however, apoptosis was suppressed. The anti-apoptotic effect of DX developed independently from its effect on MMP inhibition. The anti-apoptotic mechanism of DX in irradiated tissue needs to be further investigated.

In conclusion, single dose administration of VA and DX before irradiation exhibited a significant radio-protective effect. MMP-2 and MMP-7 activities were decreased 8 hours after radiation damage and reincreased by single dose of VA. Radiation-induced inflammatory cytokines and apoptosis were suppressed by VA simultaneously. VA and DX showed no MMP inhibitory effect in acute radiation damage and their radio-protective effects are unrelated to MMP inhibition. The mechanisms underlying the MMP modulation involved in the radio-protective effect of VA should be addressed in further studies.

Ethics Committee Approval: Ethics committee approval was received for this study from Dokuz Eylül University Ethics Committee for Animal Experimentation (permit no:82-2009).

\section{Informed Consent: N/A.}

\section{Peer-review: Externally peer-reviewed.}

Author contributions: Concept - F.H., S.T., G.O.; Design - F.H., S.T.; Supervision - F.H., G.O., S.G.A.; Resource - F.H., D.K., O.Ç., S.G.A.; Materials - D.K., Ş.I.., Z.A.,Ü.C.; Data Collection and/or Processing - F.H., D.K., Ş.İ., O.Ç., Ü.C., M.A.; Analysis and/or Interpretation - F.H., M.A., A.D.U.; Literature Search- F.H., A.D.U., Z.A.; Writing - F.H., G.O., S.T.A., D.K., A.D.U., Ü.C.; Critical Reviews - S.G.A., G.O., D.K., S.T.A., A.D.U. 
Acknowledgements: The authors would like to thank Pinar Ortan and Mustafa Delibaş for assistance and comments on this manuscript.

Conflict of Interest: No conflict of interest was declared by the authors.

Financial Disclosure: The research was financed by Dokuz Eylül University Directory of Scientific Experimental Projects, reference number 99.3456.23.

\section{REFERENCES}

1. Linard C, Ropenga A, Vozenin-Brotons M.C, Chapel A, Mathe D. Abdominal irradiation increases inflammatory cytokine expression and activates NF-kappaB in rat ileal muscularis layer. Am J Physiol Gastrointest Liver Physiol 2003;285:G556-65. [CrossRef]

2. Paris F., Fuks Z., Kang A., Capodieci P., Juan G., Ehleiter D., et al. Endothelial apoptosis as the primary lesion initiating intestinal radiation damage in mice. Science 2001;293:293-7. [CrossRef]

3. Angenete E., Langenskiöld M., Falk P., Ivarsson M.L. Matrix metalloproteinases in rectal mucosa, tumour and plasma: response after preoperative irradiation. Int J Colorectal Dis 2007;22:667-74. [CrossRef]

4. Strup-Perrot C., Vozenin-Brotons M.C., Vandamme M., Linard C., Mathé, D. Expression of matrix metalloproteinases and tissue inhibitor metalloproteinases increases in X-irradiated rat ileum despite the disappearance of CD8a T cells. World J Gastroenterol 2005;11:6312-21. [CrossRef]

5. Ito A., Mukaiyama A., Itoh Y., Nagase H., Thogersen I.B., Enghild JJ., et al. Degradation of interleukin 1beta by matrix metalloproteinases. J Biol Chem 1996;271:14657-60. [CrossRef]

6. Mohan MJ, Seaton T, Mitchell J, Howe A, Blackburn K, Burkhart $\mathrm{W}$, et al. The tumor necrosis factor-alpha converting enzyme (TACE): a unique metalloproteinase with highly defined substrate selectivity. Biochemistry 2002;4:9462-9. [CrossRef]

7. Nascimento GC, Rizzi E, Gerlach RF, Leite-Panissi CR. Expression of MMP-2 and MMP-9 in the rat trigeminal ganglion during the development of temporomandibular joint inflammation. Braz J Med Biol Res 2013;46:956-67. [CrossRef]

8. Shen LC, Chen YK, Lin LM, Shaw SY. Anti-invasion and antitumor growth effect of doxycycline treatment for human oral squamous-cell carcinoma-in vitro and in vivo studies. Oral Oncol 2010;46:178-84. [CrossRef]

9. Lee JY, Kim HS, Choi HY, Oh TH, Ju BG, Yune TY. Valproic acid attenuates blood-spinal cord barrier disruption by inhibiting matrix metalloprotease- 9 activity and improves functional recovery after spinal cord injury. J Neurochem 2012;121:81829. [CrossRef]

10. Papi A, Ferreri AM, Rocchi P, Guerra F, Orlandi M. Epigenetic modifiers as anticancer drugs: effectiveness of valproic acid in neural crest-derived tumor cells. Anticancer Res 2010;30:535-40.

11. Chung YL, Wang AJ, Yao LF. Antitumor histone deacetylase inhibitors suppress cutaneous radiation syndrome: Implications for increasing therapeutic gain in cancer radiotherapy. Mol Cancer Ther 2004;3:317-25.

12. Epperly MW, Chaillet JR, Kalash R, Shaffer B, Goff J, Franicola $\mathrm{D}$, et al. Conditional radioresistance of Tet-inducible manganese superoxide dismutase bone marrow stromal cell lines. Radiat Res 2013;180:189-204. [CrossRef]

13. Panés J, Mollà M, Casadevall M, Salas A, Sans M, Conill C, et al. Tepoxalin inhibits inflammation and microvascular dysfunction induced by abdominal irradiation in rats. Aliment Pharmacol Ther 2000;14:841-50. [CrossRef]

14. Wang Z, Leng Y, Tsai LK, Leeds P, Chuang DM. Valproic acid attenuates blood-brain barrier disruption in a rat model of transient focal cerebral ischemia: the roles of HDAC and MMP-9 inhibition. J Cereb Blood Flow Metab 2011;31:52-7. [CrossRef]

15. Grant K. DOXYCYLINE. Rat Medication Guide. 2003 June 23 (cited 2010 January 19): Available from: http://ratguide.com/ meds/antimicrobial_agents/doxycycline.php

16. Heussen C, Dowdle EB. Electrophoretic analysis of plasminogen activators in polyacrylamide gels containing sodium dodecyl sulfate and copolymerized substrates. Anal Biochem 1980;102:196-202. [CrossRef]

17. Kerr JF, Winterford CM, Harmon BV. 1994. Apoptosis. Its significance in cancer and cancer therapy. Cancer 1994;73:201326. [CrossRef]

18. Negoescu A, Lorimier P, Labat-Moleur F, Drouet C, Robert C, Guillermet $\mathrm{C}$, et al. In situ apoptotic cell labeling by the TUNEL method: improvement and evaluation on cell preparations. J Histochem Cytochem 1996;44:959-68. [CrossRef]

19. Lee WH, Warrington JP, Sonntag WE, Lee YW. Irradiation alters MMP-2/TIMP-2 system and collagen type IV degradation in brain. Int J Radiat Oncol Biol Phys 2012;82:1559-66. [CrossRef]

20. Medina C, Radomski MW. Role of matrix metalloproteinases in intestinal inflammation. Pharmacol Exp Ther 2006;318:933-38. [CrossRef]

21. Hovdenak N, Wang J, Sung CC, Kelly T, Fajardo LF, Hauer-Jensen M. Clinical significance of increased gelatinolytic activity in the rectal mucosa during external beam radiation therapy of prostate cancer. Int J Radiat Oncol Biol Phys 2002;53:919-27. [CrossRef]

22. Kumar A, Collins HM, Scholefield JH, Watson SA. Increased type-IV collagenase (MMP-2 and MMP-9) activity following preoperative radiotherapy in rectal cancer. $\mathrm{Br} J$ Cancer 2000;82:960-5. [CrossRef]

23. Kim NY, Lee JE, Chang HJ, Lim CS, Nam DH, Min BH, et al. Gamma-irradiation enhances RECK protein levels in Panc-1 pancreatic cancer cells. Mol Cells 2008;25:105-11.

24. Lint VP, Libert C. Chemokine and cytokine processing by matrix metalloproteinases and its effect on leukocyte migration and inflammation. J Leukoc Biol 2007;82:1375-80. [CrossRef]

25. Manicone AM, McGuire JK. Matrix metalloproteinases as modulators of inflammation. Semin Cell Dev Biol 2008;19:34-41. [CrossRef]

26. Zhou Y, Niu J, Li S, Hou H, Xu Y, Zhang W, et al. Radioprotective effects of valproic acid, a histone deacetylase inhibitor, in the rat brain. Biomed Rep 2015;3:63-9.

27. Zhou Y, Xu Y, Wang H, Niu J, Hou H, Jiang Y. Histone deacetylase inhibitor, valproic acid, radiosensitizes the $\mathrm{C} 6$ glioma cell line in vitro. Oncol Lett 2014;7:203-8.

28. Jantzie LL, Todd KG. Doxycycline inhibits proinflammatory cytokines but not acute cerebral cytogenesis after hypoxia-ischemia in neonatal rats. J Psychiatry Neurosci 2010;35:20-32. [CrossRef]

29. Samtani S, Amaral J, Campos MM, Fariss RN, Becerra SP. Doxycycline-mediated inhibition of choroidal neovascularization. Invest Ophthalmol Vis Sci 2010;50:5098-106. [CrossRef] 